\section{Estimation of Fruit Grade Weights Based on Fruit Number and Total Fruit Weight in Cucumber}

\author{
Nischit V. Shetty and Todd C. Wehner ${ }^{1}$ \\ Department of Horticultural Science, North Carolina State University, \\ Raleigh, NC 27695-7609
}

Additional index words. Cucumis sativus, germplasm evaluation, vegetable breeding

\begin{abstract}
In many cases, measurement of cucumber fruit weight in small research plots involves more labor and resources than just counting the number of fruit per plot. Therefore, plant breeders are interested in an efficient method for estimating fruit weight per grade (early, marketable, and cull) based on fruit number and total fruit weight. We evaluated the cucumber germplasm collection of 810 plant introduction accessions (supplied by the U.S. Dept. of Agriculture, Regional Plant Introduction Station at Ames, Iowa) along with seven check cultivars for yield. Correlations were calculated for all pairs of fruit number and fruit weight combinations for each grade. In general, the lowest correlations were observed between the fruit weight of each grade (early, marketable, and cull) and total fruit weight or number per plot. High correlations were observed for fruit weight and fruit number within each grade (early, marketable, and cull). An efficient method for estimating fruit weight per hectare of early, marketable, and cull grades is to count total, early, and cull fruit, then measure total fruit weight. Our results showed that the fruit weight of each grade (early, marketable, and cull) was best estimated using the fruit number of that grade (early, marketable, and cull) along with the total fruit weight and total fruit number.
\end{abstract}

Breeding for yield in cucumber (Cucumis sativus L.) has been a major objective of many cucumber breeding programs over the last few decades (Wehner, 1989). Measurement of yield in a diverse array of cucumber cultivars, breeding lines, and plant introduction accessions (hereafter collectively referred to as cultigens) is expensive. Cucumber breeders are interested in more efficient methods for yield measurement in test plots. Common methods used to assess yield in cucumber include measuring the number and weight of fruit for each grade, as well as the value of the fruit based on weight and grade. Fruit number was found to be more stable than fruit weight or fruit value for yield measurement in a once-over harvest of cucumber (Ells and McSay, 1981). Fruit number was also found to have a higher heritability $(0.17)$ than fruit weight (0.02) (Smith and Lower, 1978). However, fruit weight is the trait of greatest interest for breeders since that is the basis on which growers are paid. Based on our expe-

Received for publication 14 May 2001. Accepted for publication 4 Apr. 2002. Research funded by the North Carolina Agricultural Research Service (NCARS) in part by a grant from the North Carolina Pickle Producers Association. We gratefully acknowledge the technical assistance of Christopher S. Cramer, Tammy L. Ellington, and Joel L. Shuman. We also thank the USDA North Central Regional Plant Introduction Station at Ames, Iowa for kindly providing seeds for the study. The use of trade names in this publication does not imply endorsement by the NCARS of the products named, nor criticism of similar ones not mentioned.

${ }^{1}$ Professor and graduate research assistant, respectively. Direct correspondence to Todd Wehner (Todd_Wehner@NCSU.Edu). rience with yield trials in cucumber, meaplots unfortunately involves more labor and resources than counting the number of fruit. Measurement of fruit weight can also be time consuming if the weight of different grades (early, marketable, and cull) is needed. Therefore, we wanted to develop an efficient method for estimating fruit weight by grade (early, marketable, and cull) based on the number of each fruit grade along with total fruit weight.

Wehner and Miller (1984) and Wehner (1986) recommended the use of once-over harvest trials having three replications for maximum efficiency to determine which cucumber lines should be tested further in multiple-harvest trials. Swallow and Wehner (1986) found that a plot size of $1.2 \mathrm{~m} \times 1.5 \mathrm{~m}$ was optimum for yield evaluation for onceover harvest of pickling cucumber harvested using paraquat. Wehner and Miller (1987) recommended the use of small, single-row plots without end borders rather than large, multiple-row, bordered plots. In cucumber, small-plot, single-harvest trials were found to be more efficient than large-plot, multipleharvest trials (Wehner, 1986, 1989; Wehner and Miller, 1984).

Swallow and Wehner (1989) reported that maximum information (1/variance) was obtained by allocating test plots of cucumber cultigens to different seasons and years rather than different locations and replications. That was the case even though locations and replications were easier and less expensive to use than seasons and years. Finally, field evaluation at the Clinton location provided more information for a given cost than three other locations tested in North Carolina (Wehner, 1987). surement of fruit weight of cucumber in small
Robinson et al. (1968) reported that the plant growth regulator ethephon (2-chloroethanephosphonic acid) greatly increased the number of pistillate flowers in the monoecious cucumber inbred 'Wisconsin SMR 18' when applied at the first and third leaf stage. McMurray and Miller (1969) reported that the most effective concentration of ethephon to convert SC 23, a monoecious cucumber inbred, to a gynoecious one with continuous pistillate nodes was four applications at 120 ppm, or two applications at $240 \mathrm{ppm}$. The authors also reported an increase in yield and earliness due to the chemical treatment (McMurray and Miller, 1969).

Miller and Hughes (1969) recommended harvesting at the $14 \%$ to $31 \%$ oversized fruit stage ( $>51 \mathrm{~mm}$ diameter) to achieve maximum value in once-over harvest for 'Piccadilly' and 'Southern Cross' gynoecious pickling type hybrids in North Carolina. Oversize for slicing (fresh-market) cucumber would be fruit $>60 \mathrm{~mm}$ diameter. Chen et al. (1975), using a computer simulation model, reported that plots harvested at $10 \%$ oversized fruit stage gave an optimum yield for 'Piccadilly' pickling hybrid under North Carolina conditions. Colwell and O'Sullivan (1981) reported that the optimum harvest stage to maximize yield for 'Femcap' and 'Greenstar' gynoecious pickling hybrids occurred when $5 \%$ to $15 \%$ of the plot contained oversized fruit.

The objective of this experiment was to develop a set of regression equations to estimate the cucumber fruit weights by grade (early, marketable, and cull) based on individual fruit grade numbers and total fruit weight in a plot.

\section{Materials and Methods}

The experiment was conducted at the Horticultural Crops Research Station, Clinton, N.C. using recommended horticultural practices (Schultheis, 1990).

Cultural practices. Fertilizer was incorporated before planting at a rate of $90 \mathrm{~N}-39 \mathrm{P}-74 \mathrm{~K} \mathrm{~kg} / \mathrm{ha}$, with an additional $34 \mathrm{~kg} \mathrm{~N} / \mathrm{ha}$ applied at the vine tip-over stage. Curbit [ethalfluralin N-ethyl-N-(2-methyl-2 propenyl)-2,6-dinitro-4-(trifluromethyl) benzenamine] was applied for weed control. Irrigation was applied when needed for a total (irrigation plus rainfall) of 25 to $40 \mathrm{~mm}$ per week. Seeds were planted on raised, shaped beds $1.5 \mathrm{~m}$ apart on 17 Apr. 1997. Plots were $1.2 \mathrm{~m}$ long and $1.5 \mathrm{~m}$ wide with 1.2 $m$ alleys at each end. Guard rows were planted on the outside of the field, and at the end of each row. 'Sumter' pollenizer was planted on each side of the experiment as well as every 11th row, to provide pollen.

Plots were planted with 16 seeds and thinned to a uniform stand of 12 plants per plot $\approx 1$ month after planting. No disease problems were observed. Plots with a stand count (plant number) of $<50 \%$ were eliminated from the statistical analysis and plots with stand count ranging from 50\% to $80 \%$ were corrected using the formula: corrected 
yield $=($ total yield $/$ stand $) \times 10$ according to the method of Cramer and Wehner (1998).

Ethephon application. Ethephon (2chloroethyl phosphonic acid) was sprayed on seedlings at the first to second true leaf stage $\approx 5$ weeks after planting. Ethephon was prepared using Florel [3.9\% ethephon (2chloroethyl phosphonic acid)] (Southern Agricultural Insecticides, Palmetto, Fla.) at the rate of $2.5 \mathrm{~mL} \cdot \mathrm{L}^{-1}$. A Solo back-pack sprayer at 100 to $140 \mathrm{kPa}$ ( 15 to $20 \mathrm{psi}$ ) was used to spray the ethephon on the leaves and stems until run-off.

Plots were harvested once, beginning $\approx 2$ months after planting for a period of 4 weeks. Plots were harvested when $10 \%$ of the fruit in a plot were oversized $(>51 \mathrm{~mm}$ diameter for pickling cucumber and $>60 \mathrm{~mm}$ diameter for fresh market cucumber).

Cultivars evaluated. Data were taken from the U.S. Dept. of Agriculture Regional Plant Germplasm System cucumber collection in Ames, Iowa. The collection consisted of 810 plant introduction accessions originating from 50 countries along with seven check cultivars. Countries with the most accessions were Turkey, P.R. China, former Yugoslavia, Iran, former USSR, Japan, and India. The seven checks used in the experiment were 'Calypso', 'Sumter', 'Dasher II', 'Poinsett 76', 'WI2757', 'Sprint 440', and 'Marketmore 76'.

Traits measured. Data collected were number and weight of total, early, and cull fruit per plot. Early fruit were the ones that were oversized fruit at the time of once-over har- vest. Total fruit weight was the sum of early, marketable, and cull fruit per plot. The number and weight of marketable fruit was calculated as total minus cull fruit. Fruit number per plot was converted to thousands of fruit per hectare, and fruit weight per plot was converted to $\mathrm{Mg} \cdot \mathrm{ha}^{-1}$. Cultigens were classified (based on their fruit type) as pickling, slicing, middle-eastern (Beit Alpha), and oriental trellis.

Data analysis. The experiment was a randomized complete-block design with 817 cultigens and three replications. Data were analyzed using GLM and REG procedures of SAS (SAS Institute, Cary, N.C.). Regression was used to predict early fruit weight from: early number; total number; total weight; early number plus total number; early number plus total weight; total number plus total weight; and early number, total number, and total weight. Regression analyses were also used in the same way to predict marketable fruit weight and cull fruit weight.

Predicted vs. actual yield. We were interested in determining how well the predicted values were correlated with the actual data for early, marketable and cull fruit weights in the study. Prediction equations for early, marketable, and cull fruit weights were generated for each cucumber type using two of the three replications in the study in all possible combinations. The predicted early, marketable, and cull fruit weights were generated for the replication not used to develop the prediction equations.
Regression equations used were the one with the best fit for each cucumber type and yield trait (the last one in each group for Tables 1, 2, and 3). In all cases, the best fitting regression equation predicted early, marketable, or cull fruit weight using total fruit weight, total fruit number, and the number of either early, marketable, or cull fruit (depending on the trait being predicted). The predicted values for early, marketable, and cull weights were compared to the actual early, marketable, and cull weights using the CORR procedure of SAS.

\section{Results and Discussion}

Cultigens evaluated in the study differed significantly in yield as measured by early, marketable, cull, and total fruit number and weight (data not presented). Based on regression analysis between the individual fruit weight grades (early, marketable, and cull), the respective fruit numbers (early, marketable, and cull), and total fruit weight, several equations were obtained that provided good estimates of weight for each grade (Tables 13 ). The prediction equations were developed based on data that was collected on total fruit weight $\left(\mathrm{Mg} \cdot \mathrm{ha}^{-1}\right)$, total fruit number per plot, fruit number, and fruit weights for the different fruit grade types (early, marketable, and cull). The plots were classified into four distinct cucumber fruit types (pickling, slicing, middle-eastern and trellis). Since the data represent the entire cucumber germplasm

Table 1.Predicted regression equations for early fruit weight (EW) based on total fruit number (TN), early fruit number (EN), and total fruit weight (TW). ${ }^{\mathrm{z}}$

\begin{tabular}{|c|c|c|c|c|c|c|}
\hline Equation & $\mathrm{CV}$ & $R^{2}$ & Intercept & Total number & Early number & Total wt \\
\hline \multicolumn{7}{|c|}{ Pickling } \\
\hline $\mathrm{EW}=5.30+0.01(\mathrm{TN})$ & 71.52 & 0.09 & 5.30 & 0.01 & --- & --- \\
\hline $\mathrm{EW}=2.88-0.04(\mathrm{TN})+0.31(\mathrm{EN})$ & 49.14 & 0.57 & 2.88 & -0.04 & 0.31 & --- \\
\hline $\mathrm{EW}=1.30+0.27(\mathrm{EN})$ & 50.53 & 0.54 & 1.30 & --- & 0.27 & --- \\
\hline $\mathrm{EW}=-1.71+0.80(\mathrm{TW})$ & 31.89 & 0.82 & -1.71 & --- & --- & 0.80 \\
\hline $\mathrm{EW}=-2.46+0.09(\mathrm{EN})+0.65(\mathrm{TW})$ & 28.67 & 0.85 & -2.46 & --- & 0.09 & 0.65 \\
\hline $\mathrm{EW}=0.18-0.05(\mathrm{TN})+0.90(\mathrm{TW})$ & 28.16 & 0.86 & 0.18 & -0.05 & --- & 0.90 \\
\hline$E W=0.03-0.08(\mathrm{TN})+0.14(\mathrm{EN})+0.73(\mathrm{TW})^{\mathrm{y}}$ & 18.77 & 0.94 & 0.03 & -0.08 & 0.14 & 0.73 \\
\hline \multicolumn{7}{|l|}{ 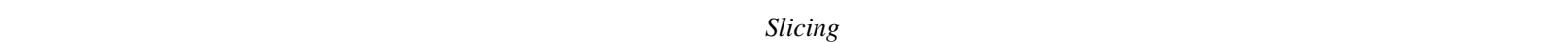 } \\
\hline $\mathrm{EW}=3.27+0.16(\mathrm{TN})$ & 79.52 & 0.23 & 3.27 & 0.16 & --- & --- \\
\hline $\mathrm{EW}=0.75+0.46(\mathrm{EN})$ & 53.74 & 0.65 & 0.75 & --- & 0.46 & --- \\
\hline $\mathrm{EW}=2.25-0.06(\mathrm{TN})+0.53(\mathrm{EN})$ & 52.71 & 0.66 & 2.25 & -0.06 & 0.53 & --- \\
\hline $\mathrm{EW}=-2.79+0.84(\mathrm{TW})$ & 31.23 & 0.88 & -2.79 & --- & --- & 0.84 \\
\hline $\mathrm{EW}=-3.11+0.10(\mathrm{EN})+0.71(\mathrm{TW})$ & 29.58 & 0.89 & -3.11 & --- & 0.10 & 0.71 \\
\hline $\mathrm{EW}=-0.58-0.09(\mathrm{TN})+1.00(\mathrm{TW})$ & 25.48 & 0.92 & -0.58 & -0.09 & --- & 1.00 \\
\hline$E W=-0.28-0.13(\mathrm{TN})+0.20(\mathrm{EN})+0.82(\mathrm{TW})^{\mathrm{y}}$ & 17.53 & 0.96 & -0.28 & -0.13 & 0.20 & \\
\hline \multicolumn{7}{|c|}{ Middle-eastern } \\
\hline $\mathrm{EW}=5.64+0.10(\mathrm{TN})$ & 64.25 & 0.12 & 5.64 & 0.10 & --- & --- \\
\hline $\mathrm{EN}=1.88+0.35(\mathrm{EN})$ & 43.88 & 0.59 & 1.88 & --- & 0.35 & --- \\
\hline $\mathrm{EW}=3.68+0.05(\mathrm{TN})+0.41(\mathrm{EN})$ & 42.34 & 0.62 & 3.68 & -0.05 & 0.41 & --- \\
\hline $\mathrm{EW}=-1.67+0.80(\mathrm{TW})$ & 27.85 & 0.83 & -1.67 & --- & --- & 0.80 \\
\hline $\mathrm{EW}=-2.28+0.12(\mathrm{EN})+0.64(\mathrm{TW})$ & 24.80 & 0.87 & -2.28 & --- & 0.12 & 0.64 \\
\hline $\mathrm{EW}=0.10-0.06(\mathrm{TN})+0.90(\mathrm{TW})$ & 24.86 & 0.87 & 0.10 & -0.06 & --- & 0.90 \\
\hline$E W=0.33-0.10(\mathrm{TN})+0.20(\mathrm{EN})+0.71(\mathrm{TW})^{\mathrm{y}}$ & 15.30 & 0.95 & 0.33 & -0.10 & 0.20 & 0.71 \\
\hline \multicolumn{7}{|c|}{ Trellis } \\
\hline $\mathrm{EW}=1.95+0.17(\mathrm{TN})$ & 67.98 & 0.29 & 1.95 & 0.17 & --- & --- \\
\hline $\mathrm{EW}=-0.18+0.56(\mathrm{EN})$ & 40.87 & 0.74 & -0.18 & --- & 0.56 & --- \\
\hline $\mathrm{EW}=0.94-0.04(\mathrm{TN})+0.62(\mathrm{EN})$ & 40.26 & 0.75 & 0.94 & -0.04 & 0.62 & --- \\
\hline $\mathrm{EW}=-1.90+0.70(\mathrm{TW})$ & 32.94 & 0.83 & -1.90 & --- & --- & 0.70 \\
\hline $\mathrm{EW}=-0.24-0.06(\mathrm{TN})+0.81(\mathrm{TW})$ & 30.83 & 0.85 & -0.24 & -0.06 & --- & 0.81 \\
\hline $\mathrm{EW}=-2.80+0.25(\mathrm{CN})+0.47(\mathrm{TW})$ & 26.61 & 0.89 & -2.80 & --- & 0.25 & 0.47 \\
\hline $\mathrm{EW}=-0.17-0.11(\mathrm{TN})+0.34(\mathrm{EN})+0.58(\mathrm{TW})^{\mathrm{y}}$ & 18.14 & 0.95 & -0.17 & -0.11 & 0.34 & 0.58 \\
\hline
\end{tabular}

${ }^{2}$ Regression calculations made with plot weights in $\mathrm{Mg} \cdot \mathrm{ha}^{-1}$ and fruit numbers in thousands/ha.

${ }^{y}$ Regression equation having the best fit to the data for each cucumber type; used for analysis in Table 4. 
Table 2. Predicted regression equations for marketable fruit weight (MW) based on total fruit number (TN), marketable fruit number (MN), and total fruit weight $(\mathrm{TW}){ }^{\mathrm{z}}$

\begin{tabular}{|c|c|c|c|c|c|c|}
\hline Equation & $\mathrm{CV}$ & $R^{2}$ & Intercept & Total number & Market number & Total wt \\
\hline \multicolumn{7}{|c|}{ Pickling } \\
\hline $\mathrm{MW}=0.78+0.16(\mathrm{TW})$ & 85.49 & 0.20 & 0.78 & --- & --- & 0.16 \\
\hline $\mathrm{MW}=0.09+0.04(\mathrm{TN})$ & 82.79 & 0.25 & 0.09 & 0.04 & --- & --- \\
\hline $\mathrm{MW}=-0.44+0.03(\mathrm{TN})+0.09(\mathrm{TW})$ & 80.07 & 0.30 & -0.44 & 0.03 & --- & 0.09 \\
\hline $\mathrm{MW}=0.68+0.00(\mathrm{TN})+0.09(\mathrm{MN})$ & 67.78 & 0.50 & 0.68 & 0.00 & 0.09 & --- \\
\hline $\mathrm{MW}=0.79+0.10(\mathrm{MN})$ & 67.76 & 0.50 & 0.79 & --- & 0.10 & --- \\
\hline $\mathrm{MW}=-0.79+0.09(\mathrm{MN})+0.12(\mathrm{TW})$ & 59.56 & 0.61 & -0.79 & --- & 0.09 & 0.12 \\
\hline $\mathrm{MW}=-0.16-0.03(\mathrm{TN})+0.12(\mathrm{MN})+0.17(\mathrm{TW})^{\mathrm{y}}$ & 56.27 & 0.66 & -0.16 & -0.03 & 0.12 & 0.17 \\
\hline \multicolumn{7}{|c|}{ Slicing } \\
\hline $\mathrm{MW}=1.95+0.11(\mathrm{TW})$ & 84.23 & 0.14 & 1.95 & --- & --- & 0.11 \\
\hline $\mathrm{MW}=0.57+0.06(\mathrm{TN})$ & 76.21 & 0.30 & 0.57 & 0.06 & --- & --- \\
\hline $\mathrm{MW}=0.54+0.06(\mathrm{TN})+0.01(\mathrm{TW})$ & 76.30 & 0.30 & 0.54 & 0.06 & --- & 0.01 \\
\hline $\mathrm{MW}=0.44+0.00(\mathrm{TN})+0.18(\mathrm{MN})$ & 48.19 & 0.72 & 0.44 & 0.00 & 0.18 & --- \\
\hline $\mathrm{MW}=0.51+0.18(\mathrm{MN})$ & 48.13 & 0.72 & 0.51 & --- & 0.18 & --- \\
\hline $\mathrm{MW}=-0.21+0.17(\mathrm{MN})+0.05(\mathrm{TW})$ & 45.74 & 0.75 & -0.21 & --- & 0.17 & 0.05 \\
\hline $\mathrm{MW}=0.09-0.02(\mathrm{TN})+0.20(\mathrm{MN})+0.08(\mathrm{TW})^{\mathrm{y}}$ & 44.23 & 0.77 & 0.09 & -0.02 & 0.20 & 0.08 \\
\hline \multicolumn{7}{|c|}{ Middle-eastern } \\
\hline $\mathrm{MW}=0.28+0.05(\mathrm{TN})$ & 80.56 & 0.23 & 0.28 & 0.05 & --- & --- \\
\hline $\mathrm{MW}=0.63+0.17(\mathrm{TW})$ & 80.61 & 0.23 & 0.63 & --- & --- & 0.17 \\
\hline $\mathrm{MW}=-0.38+0.03(\mathrm{TN}) 0.11(\mathrm{TW})$ & 77.04 & 0.30 & -0.38 & 0.03 & --- & 0.11 \\
\hline $\mathrm{MW}=0.63+0.00(\mathrm{TN})+0.16(\mathrm{MN})$ & 56.84 & 0.62 & 0.63 & 0.00 & 0.16 & --- \\
\hline $\mathrm{MW}=0.51+0.15(\mathrm{MN})$ & 56.83 & 0.62 & 0.51 & --- & 0.15 & --- \\
\hline $\mathrm{MW}=-1.00+0.13(\mathrm{MN})+0.11(\mathrm{TW})$ & 49.43 & 0.71 & -1.00 & --- & 0.13 & 0.11 \\
\hline $\mathrm{MW}=-0.32-0.04(\mathrm{TN})+0.17(\mathrm{MN})+0.16(\mathrm{TW})^{\mathrm{y}}$ & 45.03 & 0.76 & -0.32 & -0.04 & 0.17 & 0.16 \\
\hline \multicolumn{7}{|c|}{ Trellis } \\
\hline $\mathrm{MW}=0.95+0.06(\mathrm{TN})$ & 74.33 & 0.23 & 0.95 & 0.06 & --- & --- \\
\hline $\mathrm{MW}=1.38+0.15(\mathrm{TW})$ & 72.46 & 0.27 & 1.38 & --- & --- & 0.15 \\
\hline $\mathrm{MW}=0.66+0.03(\mathrm{TN})+0.10(\mathrm{TW})$ & 71.21 & 0.30 & 0.66 & 0.03 & --- & 0.10 \\
\hline $\mathrm{MW}=0.73+0.00(\mathrm{TN})+0.18(\mathrm{MN})$ & 57.41 & 0.54 & 0.73 & 0.00 & 0.18 & --- \\
\hline $\mathrm{MW}=0.97+0.18(\mathrm{MN})$ & 57.47 & 0.54 & 0.97 & --- & 0.18 & --- \\
\hline $\mathrm{MW}=-0.46+0.16(\mathrm{MN})+0.09(\mathrm{TW})$ & 51.27 & 0.64 & -0.46 & --- & 0.16 & 0.09 \\
\hline $\mathrm{MW}=0.27-0.04(\mathrm{TN})+0.20(\mathrm{MN})+0.16(\mathrm{TW})^{\mathrm{y}}$ & 47.55 & 0.69 & 0.27 & -0.04 & 0.20 & 0.16 \\
\hline
\end{tabular}

${ }^{\mathrm{R}}$ Regression calculations made with plot weights in $\mathrm{Mg} \cdot \mathrm{ha}^{-1}$ and fruit numbers in thousands/ha.

${ }^{y}$ Regression equation having the best fit to the data for each cucumber type; used for analysis in Table 4.

Table 3. Predicted regression equations for cull fruit weight $(\mathrm{CW})$ based on total fruit number (TN), cull fruit number $(\mathrm{CN})$, and total fruit weight $(\mathrm{TW}){ }^{\mathrm{z}}$

\begin{tabular}{|c|c|c|c|c|c|c|}
\hline Equation & $\mathrm{CV}$ & $R^{2}$ & Intercept & Total number & Cull number & Total w \\
\hline \multicolumn{7}{|c|}{ Pickling } \\
\hline $\mathrm{CW}=0.93+0.04(\mathrm{TW})$ & 94.35 & 0.05 & 0.93 & --- & --- & 0.04 \\
\hline $\mathrm{CW}=0.28+0.02(\mathrm{TN})$ & 88.11 & 0.17 & 0.28 & 0.02 & --- & --- \\
\hline $\mathrm{CW}=0.26+0.02(\mathrm{TN})+0.00(\mathrm{TW})$ & 88.16 & 0.17 & 0.26 & 0.02 & --- & 0.00 \\
\hline $\mathrm{CW}=0.42+0.0(\mathrm{TN})+0.08(\mathrm{CN})$ & 58.74 & 0.63 & 0.42 & 0.00 & 0.08 & --- \\
\hline $\mathrm{CW}=0.34+0.08(\mathrm{CN})$ & 58.78 & 0.63 & 0.34 & --- & 0.08 & --- \\
\hline $\mathrm{CW}=-0.07+0.08(\mathrm{CN})+0.03(\mathrm{TW})$ & 56.57 & 0.66 & -0.07 & --- & 0.08 & 0.03 \\
\hline $\mathrm{CW}=0.15-0.01(\mathrm{TN})+0.09(\mathrm{CN})+0.05(\mathrm{TW})^{\mathrm{y}}$ & 54.63 & 0.68 & 0.15 & -0.01 & 0.09 & 0.05 \\
\hline \multicolumn{7}{|c|}{ Slicing } \\
\hline $\mathrm{CW}=0.83+0.05(\mathrm{TW})$ & 110.07 & 0.10 & 0.83 & --- & --- & 0.05 \\
\hline $\mathrm{CW}=0.01+0.03(\mathrm{TN})$ & 100.14 & 0.25 & 0.01 & 0.03 & --- & --- \\
\hline $\mathrm{CW}=0.04+0.03(\mathrm{TN})-0.01(\mathrm{TW})$ & 100.24 & 0.25 & 0.04 & 0.03 & --- & -0.01 \\
\hline $\mathrm{CW}=0.27+0.00(\mathrm{TN})+0.10(\mathrm{CN})$ & 77.49 & 0.55 & 0.27 & 0.00 & 0.10 & --- \\
\hline $\mathrm{CW}=0.48+0.10(\mathrm{CN})$ & 77.76 & 0.55 & 0.48 & --- & 0.10 & --- \\
\hline $\mathrm{CW}=-0.04+0.10(\mathrm{CN})+0.03(\mathrm{TW})$ & 74.61 & 0.59 & -0.04 & --- & 0.10 & 0.03 \\
\hline $\mathrm{CW}=0.12-0.01(\mathrm{TN})+0.11(\mathrm{CN})+0.05(\mathrm{TW})^{\mathrm{y}}$ & 73.76 & 0.60 & 0.12 & -0.01 & 0.11 & 0.05 \\
\hline \multicolumn{7}{|c|}{ Middle-eastern } \\
\hline $\mathrm{CW}=1.04+0.04(\mathrm{TW})$ & 101.28 & 0.03 & 1.04 & --- & --- & 0.04 \\
\hline $\mathrm{CW}=0.20+0.02(\mathrm{TN})$ & 93.98 & 0.17 & 0.20 & 0.02 & --- & --- \\
\hline $\mathrm{CW}=0.27+0.03(\mathrm{TN})-0.01(\mathrm{TW})$ & 93.92 & 0.17 & 0.27 & 0.03 & --- & 0.01 \\
\hline $\mathrm{CW}=0.45+0.00(\mathrm{TN})+0.09(\mathrm{CN})$ & 68.91 & 0.55 & 0.45 & 0.00 & 0.09 & --- \\
\hline $\mathrm{CW}=0.40+0.09(\mathrm{CN})$ & 68.88 & 0.55 & 0.40 & -.- & 0.09 & --- \\
\hline $\mathrm{CW}=-0.15+0.09(\mathrm{CN})+0.03(\mathrm{TW})$ & 66.40 & 0.59 & -0.15 & --- & 0.09 & 0.03 \\
\hline${ }^{\mathrm{y}} \mathrm{CW}=0.10-0.02(\mathrm{TN})+0.11(\mathrm{CN})+0.06(\mathrm{TW})$ & 63.70 & 0.62 & 0.10 & -0.02 & 0.11 & 0.06 \\
\hline \multicolumn{7}{|c|}{ Trellis } \\
\hline $\mathrm{CW}=-0.19+0.06(\mathrm{TN})$ & 82.99 & 0.30 & -0.19 & 0.06 & --- & --- \\
\hline $\mathrm{CW}=0.52+0.15(\mathrm{TW})$ & 83.14 & 0.30 & 0.52 & --- & --- & 0.15 \\
\hline $\mathrm{CW}=-0.43+0.04(\mathrm{TN})+0.09(\mathrm{TW})$ & 79.97 & 0.35 & -0.43 & 0.04 & --- & 0.09 \\
\hline $\mathrm{CW}=0.59+0.16(\mathrm{CN})$ & 67.06 & 0.54 & 0.59 & --- & 0.16 & --- \\
\hline $\mathrm{CW}=0.22+0.01(\mathrm{TN})+0.14(\mathrm{CN})$ & 66.80 & 0.55 & 0.22 & 0.01 & 0.14 & --- \\
\hline $\mathrm{CW}=-0.88+0.13(\mathrm{CN})+0.09(\mathrm{TW})$ & 58.65 & 0.65 & -0.88 & --- & 0.13 & 0.09 \\
\hline $\mathrm{CW}=-0.11-0.05(\mathrm{TN})+0.18(\mathrm{CN})+0.16(\mathrm{TW})^{\mathrm{y}}$ & 54.18 & 0.70 & -0.11 & -0.05 & 0.18 & 0.16 \\
\hline
\end{tabular}

${ }^{2}$ Regression calculations made with plot weights in $\mathrm{Mg} \cdot h \mathrm{~h}^{-1}$ and fruit numbers in thousands/ha.

${ }^{y}$ Regression equation having the best fit to the data for each cucumber type; used for analysis in Table 4. 
collection, the prediction equations we have proposed are the most conservative for their respective classes. However, the prediction equations may change for different sets of cultigens and environments.

The prediction equations in the tables apply to each of the cucumber types (pickling, slicing, middle-eastern, and trellis). If data is collected on total fruit number and/or fruit number of each grade (early, marketable, and cull) and/or total fruit weight per plot, then one could estimate the early, marequations in Tables 1-3. For example, if one was working with slicing cucumber and had data for early fruit number (number/ha), total fruit number (no./ha), and total fruit weight $\left(\mathrm{Mg} \cdot \mathrm{ha}^{-1}\right)$, then early fruit weight $\left(\mathrm{Mg} \cdot \mathrm{ha}^{-1}\right)$ would be estimated using the formula: early fruit weight $=-0.28-0.13$ (total fruit number) +0.20 (early fruit number) +0.82 (total fruit weight). The prediction equation had an $R^{2}$ of 0.96 and a CV of 17.53 for the early fruit weight that was actually measured (Table 1 ).

Correlations between early, marketable, or cull fruit weight and the other traits (total, early, marketable, or cull number, and total fruit weight) ranged from a minimum of 0.03 (correlation between cull fruit weight and total fruit weight for the middle-eastern type, Table 3) to a maximum of 0.96 (correlation between early fruit weight and early fruit number, total fruit number, and total fruit weight for slicers, Table 1).

Prediction of early fruit weight. There was a wide range in correlation between early ent cucumber fruit grades. The lowest $R^{2}$ value measured was 0.09 for early fruit weight estimated from total fruit number (pickling type); the highest $R^{2}$ was 0.96 for early fruit weight estimated from early fruit number, total fruit number, and total fruit weight (slicing type).

In general, the lowest correlations were between total fruit number and early fruit weight. The other grades measured were intermediate to high in their $R^{2}$ values. The trait combination that provided the best correlation with early marketable weight were early fruit number, total fruit number, and total fruit weight ( $R^{2}$ range 0.93 to 0.96 , Table 1$)$.

Prediction of marketable fruit weight. ketable, and cull fruit weight based on the fruit weight and the fruit number of the differ-

There were differences in the correlation values $\left(R^{2}\right)$ between marketable fruit weight and the weights of the other grades measured. The range in $R^{2}$ varied from 0.14 to 0.77 (Table 2). The highest correlation values were observed when marketable fruit weight was regressed on marketable fruit number, total fruit number, and total fruit weight for all the fruit types (Table 2)

In general, the highest correlations for marketable fruit weight across all cucumber types were obtained when marketable fruit weight was regressed on either marketable fruit number and total fruit weight, or on marketable fruit number, total fruit number, and total fruit weight. The $R^{2}$ values were found to be intermediate when regression was computed to total fruit number and total fruit weight, marketable fruit number, and total fruit number and marketable fruit number. $R^{2}$ values were smallest when regression was based only on total fruit number or total fruit weight (Table 2).

Prediction of cull fruit weight. Large differences in correlation were observed when cull fruit weight was regressed on fruit weight or number of the different grades. The highest correlations ( $R^{2}$ values) across all cucumber types was observed when cull fruit weight was regressed on cull fruit number and total fruit weight, or on cull fruit number, total fruit number, and total fruit weight. Correlations were low when cull fruit weight per plot was regressed on total fruit weight, on total fruit number, or on total fruit weight and number (Table 3).

In general, the lowest correlations across all fruit types were observed between fruit grade weights (early, marketable, and cull) and total fruit weight or total fruit number. The highest correlations across all cucumber fruit types were observed between fruit grade weights (early, marketable, and cull) and fruit number for each grade (total and early, marketable, or cull) along with total fruit weight. Estimation of early fruit weight from early fruit number, total fruit number, and total fruit weight had the highest predictive value ( $R^{2}$ range 0.93 to 0.96 , Table 1$)$. Next highest predictive value was for estimation of marketable fruit weight from marketable fruit number, total fruit number, and total fruit weight ( $R^{2}$ range 0.66 to 0.77 , Table 2 ).

Table 4. Correlations between actual and predicted weight for early, marketable, and cull fruit grades, using two replications to generate the regression equations, and one replication to test predicted vs. actual weight. $^{\mathrm{z}}$

\begin{tabular}{lcccc}
\hline & & \multicolumn{3}{c}{ Mean correlation $(r)^{\mathrm{y}}$} \\
\cline { 3 - 5 } Cucumber type & $\begin{array}{c}\text { No. cultigens } \\
\text { per type }\end{array}$ & $\begin{array}{c}\text { Predicted vs. actual } \\
\text { early fruit wt }\end{array}$ & $\begin{array}{c}\text { Predicted vs. actual } \\
\text { marketable fruit wt }\end{array}$ & $\begin{array}{c}\text { Predicted vs. actual } \\
\text { cull fruit wt }\end{array}$ \\
\hline Pickling & 258 & $0.65^{* *}$ & $0.48^{* *}$ & $0.57^{* *}$ \\
Slicing & 113 & $0.63^{* *}$ & $0.67^{* *}$ & $0.51^{* *}$ \\
Middle-eastern & 262 & $0.60^{* *}$ & $0.52^{* *}$ & $0.51^{* *}$ \\
Trellis & 173 & $0.63^{* *}$ & $0.51^{* *}$ & $0.55^{* *}$
\end{tabular}

${ }^{2}$ Regression equations used were the one with the best fit for each cucumber type and yield trait (the last one in each group in Tables 1-3). In all cases, the best fitting regression equation predicted early, marketable, or cull fruit weight using total fruit weight, total fruit number, and the number of either early, marketable, or cull weight (depending on the trait being predicted).

${ }^{y}$ Correlations are the mean of the three possible combinations of removing one replication from the three replications of the dataset, consisting of 817 cultigens per replication.

${ }^{* *}$ Significant at the $1 \%$ level.
The lowest predictive value was for estimation of cull fruit weight from cull fruit number, total fruit number, and total fruit weight ( $R^{2}$ range 0.60 to 0.70 , Table 3 ).

Predicted $v$ s. actual yield. The prediction equations for early, marketable, and cull fruit weights were developed using one set of the data, and used to generate predicted yields in another set of the data. Correlation of predicted with actual weight for each grade ranged from 0.48 to 0.65 (Table 4) for the average of the three possible combinations of data. Thus, the prediction equations worked well, but were not as good as making the actual measurement of weight for each fruit grade.

In summary, the fruit weight of each grade (early, marketable, and cull) can be estimated, with a good correlation to actual weight. The data is best estimated using the fruit number of that grade, along with the total fruit weight and total fruit number. The next best alternatives would be to use fruit number of a particular grade along with total weight (for estimating marketable and culled fruit weights) or using total fruit number and total fruit weight (for predicting early fruit weight). However, if one had to choose just one trait for predicting fruit grade weights due to lack of resources, we recommend the use of total fruit weight in a plot along with early fruit number $\left(R^{2}\right.$ range 0.54 to 0.74 , Table 1), marketable fruit number $\left(R^{2}\right.$ range 0.50 to 0.72 , Table 2 ), and cull fruit number ( $R^{2}$ range 0.55 to 0.63 ) (Table 3 ) for estimating the weights of early, marketable, and cull fruit.

\section{Literature Cited}

Chen, L.H., C.H. Miller, and R.S. Sowell. 1975 Simulation models for harvesting of pickling cucumbers. J. Amer. Soc. Hort. Sci. 100:176179.

Colwell, H.T.M. and J. O'Sullivan. 1981. Economics of harvest timing for once over harvesting of cucumbers. J. Amer. Soc. Hort. Sci. 106:163-167.

Cramer, C.S. and T.C. Wehner. 1998. Stand correction methods for cucumber fruit yield. $\mathrm{Cu}$ curbit Genet. Coop. Rpt. 21:18-20.

Ells, J.E. and A.E. McSay. 1981. Yield comparisons of pickling cucumber cultivar trials for once-over harvesting. HortScience 16:187-189.

McMurray, A.L. and C.H. Miller. 1968. Cucumber sex expression modified by 2 -chloroethanephosphonic acid. Science 162:396-397.

Miller, C.H. and G.R. Hughes. 1969. Harvest indices for pickling cucumbers in once-over harvest systems. J. Amer. Soc. Hort. Sci. 94:485-487.

Robinson, R.W., S. Shannon, and M.D. de la Guardia. 1968. Regulation of sex expression in the cucumber. BioScience 19:141-142.

Schultheis, J.R. 1990. Pickling cucumbers. N.C. State Agr. Ext. Hort. Info. Lflt. No. 14-A

Smith, O.S. and R.L. Lower. 1978. Field plot techniques for selecting increased once-over harvest yields in pickling cucumbers. J. Amer. Soc. Hort. Sci. 103:92-94.

Swallow, W.H. and T.C. Wehner. 1986. Optimum plot size for measurement of yield in multiple and once over harvest trials of pickling and fresh market cucumbers. Euphytica 35:493501. 
Swallow, W.H. and T.C. Wehner. 1989. Optimum allocation of plots to years, seasons, locations, and replications, and its applications to once-over harvest cucumber trials. Euphytica 43:59-68.

Wehner, T.C. 1986. Efficiency of 3 single-harvest tests for evaluation of yield in pickling cucumber. Euphytica 35:493-501.
Wehner, T.C. 1987. Value of 12 season-location combinations for cucumber yield trials in North Carolina. Cucurbit Genet. Coop. Rpt. 6:38-39.

Wehner, T.C. 1989. Breeding for improved yield in cucumber. In: J. Janick (ed.). Plant Breed. Rev. Vol. 6:323-359.

Wehner, T.C. and C.H. Miller. 1984. Efficiency of single-harvest methods for measurement of yield in fresh-market cucumbers. J. Amer. Soc. Hort. Sci. 109:659-664.

Wehner, T.C. and C.H. Miller. 1987. Optimum plant density for multiple-harvest yield of determinate cucumbers. Cucurbit Genet. Coop. Rpt. 10:29-30. 